\title{
Impact of Performance Appraisal on Employee Performance in Private Sector Banks of District Aligarh
}

\author{
Unnati Jadaun, Saurabh Kumar
}

\begin{abstract}
As we all know Human Resources are the most vital component of an organization. To succeed in this competitive era, an organization must possess effective and efficient human resource in every manner. Hence after the selection employee, he has been trained and motivated. For this evaluation of the performance of an employee is needed. This process of evaluation is known as Performance Appraisal. With the help of systematic appraisal methods, corporate performance can be enhanced. It is basically to know the value of an employee qualitatively. It is indispensable tool for every organization for measuring the effectiveness of the employee. This research study has been done to understand the impact of Performance Appraisal on Employee performance in Private sector banks of district Aligarh. In this study, researcher selected two private sector banks ICICI and Axis bank with the sample size of 100. Researcher used Linear Regression as statistical tool for data analysis.
\end{abstract}

Index Terms: Employee Performance, Linear Regression, Performance Appraisal.

\section{INTRODUCTION}

As we all know Human Resources are the most vital component of an organization. To succeed in this competitive era, an organization must possess effective and efficient human resource in every manner. Hence after the selection employee, he has been trained and motivated. For this evaluation of the performance of an employee is needed. This process of evaluation is known as Performance Appraisal. With the help of systematic appraisal methods, corporate performance can be enhanced. It is basically to know the value of an employee qualitatively. It is indispensable tool for every organization for measuring the effectiveness of the employee.

In this world, there are many kinds of people with different abilities, skills, and aptitudes etc. So that there is a difference in the quality and quantity of work which has been done by them. Therefore, appraisal has been given to employees by understanding their abilities and talents.

As name suggest, performance appraisal is all about performance that is given by employees towards their organization. If the process of performance appraisal will be well designed, then it will definitely help employees to understand their duties and responsibilities which they have towards the organization. Performance appraisal acts as a

Revised Manuscript Received on July 5, 2019.

Unnati Jadaun, IBM, Mangalayatan University, Aligarh, India,

Dr. Saurabh Kumar, IBM, Mangalayatan University, Aligarh, India. tool which is used for making the employees perfect in their field.

Performance Appraisal is a process of providing valuable opportunity to the employees so that organization can focus on objectives achievements. It is basically for identifying problems, rectifying them, and encouraging the better performance. However, the benefits of Performance Appraisal can be discussed as below:

Motivation: Performance Appraisal is a significant tool for enhancing the motivation and satisfaction level of employees. It can be in directions, Better as well as worse. Performance Appraisal provides recognition for putting their efforts in getting objective achievements. Effective Performance Appraisal system is an indication to employee that organization is interested in the growth and development of employees which results in positive impact on employee's commitment.

Training and Development: With the help of systematic Performance Appraisal, the need of training and development can be known. The weaknesses of employee can be known so that training and development exercises have been imparted to them for removing that weakness.

Recruitment and Induction: Through the appraisal data, organization can modify the recruitment strategies. It can be used in monitoring the success of recruitment process.

Employee Evaluation: As name suggests, Performance Appraisal is the process of evaluation of employees. Evaluation is needed to boost and develop employee's skills.

Career Planning and Development: Performance Appraisal helps organization as well as employees. The feedback on performance guide employees to take their career decisions for the future purpose.

Placement Decisions: With the help of Performance Appraisal various decision related to placement has been taken such as transfers, promotion and demotions etc.

Employee performance means that employee's work accomplishment after applying all the required efforts on the job which is related to getting a meaningful work, sympathetic colleagues and senior employees all around. For utilizing Human Resource 
fully, and for getting desirable results, it's essential to adopt an effective employee performance management system by the organization.

\section{REVIEW OF LITERATURE}

Yaseen A. in the study, uncovered that Performance appraisal has key significance in any association and said that it is obligatory to utilize unique performance evaluation frameworks in a proper approach to get honest results in the association. Asrar H. et al. in their study, uncovered that Pakistani banking trade is lingering a long way behind the outside banks working in our closeness, helping the indistinguishable market. The banking trade is yet not outfitted with the plans basic to battle in a profoundly powerful banking domain. The key contributory part to fault for the flourishing usage of PMS is the solid guarantee and mentality displayed by the bosses in particular and subordinates as a rule. Proper instructing of labourers would guaranty be able to the fair assessment. It has more remote been acknowledged by the vast majority of the organizations that the talented Human Resource, if reasonably developed, can supply the equivalent for show over the affray for long circumstances to come. Be that as it may, acquiring and keeping talented specialists isn't a so clear undertaking, and is in detail an issue inverse association. Associations give work various motivational and duty benefitting techniques to twofold check long run association and high review of specialist strong guarantee PMS being the key gadget in such manner. Showkat S. in her study supported the view that performance appraisal system ought to be HRD situated. Other than being a base for settling on managerial and formative choices, performance appraisal can be helpful tool for maintaining a cordial relationship with employees, planning employee's performance and finding potential of employees and enhancing organizational effectiveness. Shrivastava P. and Rai U.K. in their study stated that Performance Appraisal typically reviews past conduct thus gives a chance to consider past execution of the bank employees. It may be fruitful when they can be utilized as a reason for making improvement and change designs and attaining understanding about upgrading the bank's impact and viability later on. Performance Appraisal is considered as backbone of performance management in the bank to keep them with the high inspiration and motivation. Shrivastava A. and Purang P. found Performance appraisal as the most critical human resource practice and an essential part of each and every organization; however, the practice continues to generate dissatisfaction among employees and sometimes it is viewed as unfair and ineffective. According to results of this study, they found that private sector bank employees are more satisfied with their performance appraisal system in comparison of employees of private sector bank employees. Mukulu E. in his study learned about Human assets are a standout amongst the most basic parts of key accomplishment over all associations. For one to impartially judge the HR management practices compelling; they should add to the association's primary concern. Reward and pay procedures have a more prominent part in affecting the performance of bank employees consequently contribute intensely to the performance of commercial banks in Kenya.

\section{OBJECTIVE}

To ascertain the impact of Performance Appraisal on performance of employees in private sector banks of district Aligarh.

\section{HYPOTHESIS}

$\mathrm{H}_{0}$ : There is no impact of Performance Appraisal on performance of employees in private sector banks of district Aligarh.

\section{RESEARCH METHODOLOGY}

Research Design:

Descriptive

Sample Area:

Sample Size: ICICI and Axis banks of Aligarh

Sampling Technique: Random sampling of 50 employees from both banks.

Data Collection tool: Primary data has been collected through questionnaire filled by the bank employees.

Statistical tool: Linear Regression

\section{DATA ANALYSIS \& INERPRETATION}

\begin{tabular}{|l|c|r|c|c|}
\hline \multicolumn{7}{|c|}{ Model Summary } \\
\hline Model & \multicolumn{1}{|c|}{$\mathrm{R}$} & R Square & $\begin{array}{c}\text { Adjusted R } \\
\text { Square }\end{array}$ & $\begin{array}{c}\text { Std. Error } \\
\text { of the } \\
\text { Estimate }\end{array}$ \\
\hline 1 & $.220^{\mathrm{a}}$ & .048 & .039 & .35256 \\
\hline \multicolumn{2}{|l}{ a. Predictors: (Constant), PA } \\
\hline
\end{tabular}

\begin{tabular}{|l|c|c|l|}
\hline \multicolumn{4}{|c|}{ Variables Entered/Removed $^{\mathrm{a}}$} \\
\hline Model & $\begin{array}{c}\text { Variables } \\
\text { Entered }\end{array}$ & $\begin{array}{c}\text { Variables } \\
\text { Removed }\end{array}$ & Method \\
\hline 1 & PA $^{\mathrm{b}}$ & & Enter \\
\hline a. Dependent Variable: EP & \\
\hline
\end{tabular}

\begin{tabular}{|c|c|c|c|c|c|c|}
\hline \multicolumn{7}{|c|}{ ANOVA $^{a}$} \\
\hline \multicolumn{2}{|l|}{ Model } & $\begin{array}{c}\text { Sum of } \\
\text { Squares }\end{array}$ & df & $\begin{array}{c}\text { Mean } \\
\text { Square }\end{array}$ & $\mathrm{F}$ & Sig. \\
\hline \multirow[t]{3}{*}{1} & \begin{tabular}{|l|} 
Regres \\
sion
\end{tabular} & .617 & 1 & .617 & $\begin{array}{r}4.96 \\
5 \\
\end{array}$ & $.028^{\mathrm{b}}$ \\
\hline & $\begin{array}{l}\text { Residu } \\
\text { al }\end{array}$ & 12.181 & 98 & .124 & & \\
\hline & Total & 12.799 & 99 & & & \\
\hline \multicolumn{7}{|c|}{ a. Dependent Variable: EP } \\
\hline b. Pre & $(\mathrm{C}$ & nstant), $\mathrm{PA}$ & & & & \\
\hline
\end{tabular}

\section{Inference:}

From the above results, it can be concluded that Performance Appraisal was found to be affecting Employee Performance. 


\section{HYPOTHESIS TESTING}

As per the results of the above hypothesis, Performance Appraisal significantly affects Employee Performance in private sector banks of district Aligarh. Therefore, the above Hypothesis is rejected.

\section{LIMITATIONS}

1. The study was administered in Aligarh district only.

2. Researcher had a limited time and resources but she had tried her best to complete this research fairly.

\section{CONCLUSION}

This research paper examines the impact of performance appraisal on employee performance. The results of the study showed that performance appraisal practices of the bank affect the performance of employee. Employee's performance can be increased by through financial benefits. Performance appraisal ensures motivation and efficiency of employees. This process is necessary to maintain the consistency of employee's performance. There is a competitive era in commercial banks, in order to survive with this competition satisfaction of employees is much needed. Satisfied employees can work better with all their efficiency and effectiveness, satisfaction can be done only by proper performance appraisal system without any kind of biasness.

\section{REFERENCES}

1. Yaseen, A. (2015) “ Performance Management Practices and its impact on bank's performance in Pakistan", International Journal of Human Resources, 5, pp- 110-127.

2 Asrar, H., Rizwan, M., Pasha, S., and Usmani, W.U. (2015), "Analysis of Performance Management System in Pakistan Banking Industry", International Journal of Management Sciences and Business Research, 4 , pp- $1-5$.

3. Mukulu,E.(2014)“Effect of reward and compensation strategies on the performance of commercial banks in Kenya", 2, pp- 1-20

4. Showkat, S. (2013) "Performance Appraisal in Banking Organizations", International Refereed Research Journal, Volume 4, pp- 66-79.

5. Shrivastava, P. and Rai U.K. (2012) "Performance Appraisal Practices In Indian Banks", Integral Review - A Journal of Management, 5, pp 46-52.

6. Shrivastava, A. and Purang P. (2011) "Employee perceptions of performance appraisals: a comparative study on Indian banks", The International Journal of Human Resource Management, 22, pp632-647.

\section{AUTHORS PROFILE}

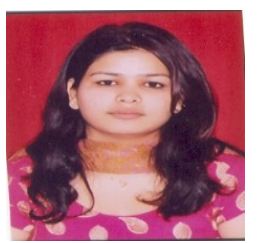

Unnati Jadaun

Assistant Professor,

MBA, UGC-JRF

Institute of Business Management, Mangalayatan

University Aligarh

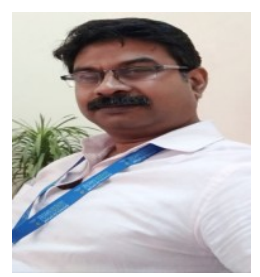

Dr. Saurabh Kumar

Associate Professor,

M.com, M.B.A., L.L.B., Ph.D. (Commerce)

Institute of Business Management, Mangalayatan

University Aligarh 